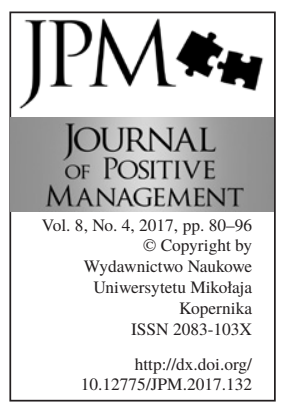

\title{
THE EFFECTS OF ORGANIZATIONAL CULTURE, LEADERSHIP BEHAVIOR, AND JOB SATISFACTION ON EMPLOYEE ORGANIZATIONAL COMMITMENT
}

\author{
${ }^{a}$ Sri Yanti, ${ }^{b} J a r n a w i$ Afgani Dahlan \\ ${ }^{a}$ Universitas Islam Syekh-Yusuf Tangerang Banten, \\ Management Department \\ ${ }^{\mathrm{b}}$ Universitas Pendidikan Indonesia, Department of Mathematics Education \\ ae-mail: sri.yanti@unis.ac.id \\ be-mail: jarnawi@upi.edu
}

\begin{abstract}
The objective of this research is to study the effects of organizational culture, leadership behavior and job satisfaction on organizational commitment at the Technical Implementation Unit of Education Office in Tangerang Regency. This research used the quantitative approach with survey method. The samples of this research were 121 employees selected randomly. The data were obtained by distributing questionnaires and analyzed by using descriptive statistics and structural equation modeling (SEM) in inferential statistics. The results of the research show that: (1) organizational culture had a direct effect on employee job satisfaction, (2) organizational culture had a direct effect on employee organizational commitment, (3) leadership behavior had a direct effect on employee job satisfaction, (4) leadership behavior had a direct effect on employee organizational commitment, and (5) job satisfaction had a direct effect on employee organizational commitment. Therefore, to improve employee organizational commitment, organizational culture, leadership behavior and job satisfaction should be improved.
\end{abstract}

Keywords: organizational culture, leadership behavior, job satisfaction, organizational commitment Paper type: Research paper

\section{Introduction}

The implementation of education from time to time has become the center of attention of various groups, such as educational practitioners, learners, parents, and users of education output. This is so because the administration of education determines the quality of education provided by educational institutions as embodied in the graduates as human resources (HR) who play an important role 
in various sectors of life and national development. With such conditions, the parties involved in the process of education also have always been in the public spotlight, including the non-functional employees in the regencies who work at the Technical Implementation Unit (UPT) of the Education Office in charge of providing full support for the activities of functional personnel (teachers) spread in schools.

More specifically, the Technical Implementation Unit of Kindergarten, Primary School, and Non-formal and Informal Education manages primary education which lays the foundation for the next level of education, making it acquire a strategic role in the implementation of education. Thus, the task of this technical implementation unit is fundamental to and strategic in the implementation of the next level of education.

One of the aspects that need more attention is the organizational commitment of non-functional employees at the technical implementation unit of kindergarten, primary school, and non-formal and informal education as the drive of the administration of primary education. Organizational commitment is really necessary because individuals with high organizational commitment will constantly strive for organizational progress. In this regard, organizational commitment is at least related to the self-identification of organizational values, goals, and objectives; engagement and willingness to strive optimally for the interest of the organization; and a strong desire to continue being a member of the organization (Newstrom and Davis, 2007). All of these elements of organizational commitment are needed by any organization, not least educational organization, especially to improve the quality of education services and education in general, and to answer the challenges of global civilization.

Organizational commitment is not solely triggered by the internal factors of the individuals, but can also be caused by external factors. Three important variables that potentially influence organizational commitment are organizational culture (Colquitt et al., 2009; Silverthorne, 2004; Sosa and Sagas, 2006; Canessa and Riolo, 2003), leadership behavior (Walumbwa et al., 2005), and job satisfaction (Colquitt et al., 2009).

Organizational culture is a collection of values that are established and upheld by all members of an organization; the values are referenced by the members of the organization in speaking, acting, and behaving and furthermore in solving problems of the organization and its me mers (Zachary and Kuzuhara, 2005). An organization that has excellent values that are massively inculcated in its employees will be a role model for the employees in carrying out their daily duties. Under these conditions, organizational culture can trigger and spur employees' commitment to the organization (Ingersoll et al., 2000). The positive values of the organization are also the spirits that become an important basis for building the morale of the members of the organization.
THE EFFECTS OF ORGANIZATIONAL CULTURE

Sri Yanti, Jarnawi Afgani Dahlan 
THE EFFECTS OF ORGANIZATIONAL CULTURE

Sri Yanti,

Jarnawi Afgani Dahlan
The enthusiasm to work is also an important pillar in helping build strong commitment to the organization. Not only does organizational culture have an impact on organizational commitment, it is also a potential factor in promoting job satisfaction. Organizations that seek to develop respect for their members by treating employees as important organizational assets will encourage a growing sense of satisfaction at work.

Regarding leadership behavior, it can be defined as a central and vital factor for the organization (Girl, 2009; Wiwoho, 2004; Azwar, 2003). This is related to the role of leader as a source of influence for the organization and all members within it. The vitality of a leader's role brings so widespread and substantive impacts on the organization and all its members that the leader becomes the focus of all members of the organization. If the leadership behavior displayed by a leader is perceived positively by members of the organization, the behavior will lead to positive attitudes and behavior among members of the organization. Conversely, if the leadership behavior displayed by a leader is perceived negatively, it will lead to the emergence of negative attitudes and behavior of members of the organization (Robbins and Judge, 2009; Daft and Macrcic, 2008; Greenberg and Baron, 2008). The attitudes and behavior can be seen in the employee commitment to the organization. This implies that leadership behavior is an antecedent or a factor affecting employee organizational commitment. The behavior displayed by the leader also has a potential impact on job satisfaction. If subordinates feel rewarded for their work by the leader, given the flexibility to perform the task, given the motivation to work, and are always directed and guided, their work satisfaction will grow (Zhu et al., 2005).

The same thing applies to job satisfaction. As a psychological aspect of work, job satisfaction is needed by employees to build their commitment to the organization. In this regard, job satisfaction reflects the psychological atmosphere and the relative feelings of a person in perceiving his/her work or aspects in the work. If the work or any of its aspects can bring satisfaction, then employees will be more dedicated in work, more vigorous, and diligent. Work satisfaction can also encourage the growth of loyalty and strong willingness to contribute to the organization, all of which is the essence of employee organizational commitment.

In line with the above description, the phenomenon in the field shows that there are officers of the Technical Implementation Unit of Kindergarten, Primary School, and Non-formal and Informal Education (hereinafter referred to as Technical Implementation Unit) at the Education Office of Tangerang Regency who are still not fully committed to their organization. The indications are, among others, employee behavior that can be detrimental to the agency such as using office facilities for personal use, using work hours for personal matters, taking breaks more than the allocated time, paying less attention to commands or supervising superiors, and violating prevailing work terms and regulations. 
This condition has prompted the researchers to do research on employee organizational com mitment from the perspective of organizational culture, leadership behavior, and job satisfaction by taking the title: "The Effects of Organizational Culture, Leadership Behavior, and Job Satisfaction on Employee Organizational Commitment: A Causal Study at the Technical Implementation Unit of Education Office in Tangerang Regency."

\section{Research hypothesis model}

The hypothesis model of the present research that describes the effects of organizational culture, leadership behavior, and job satisfaction on organizational commitment is illustrated in Figure 1.

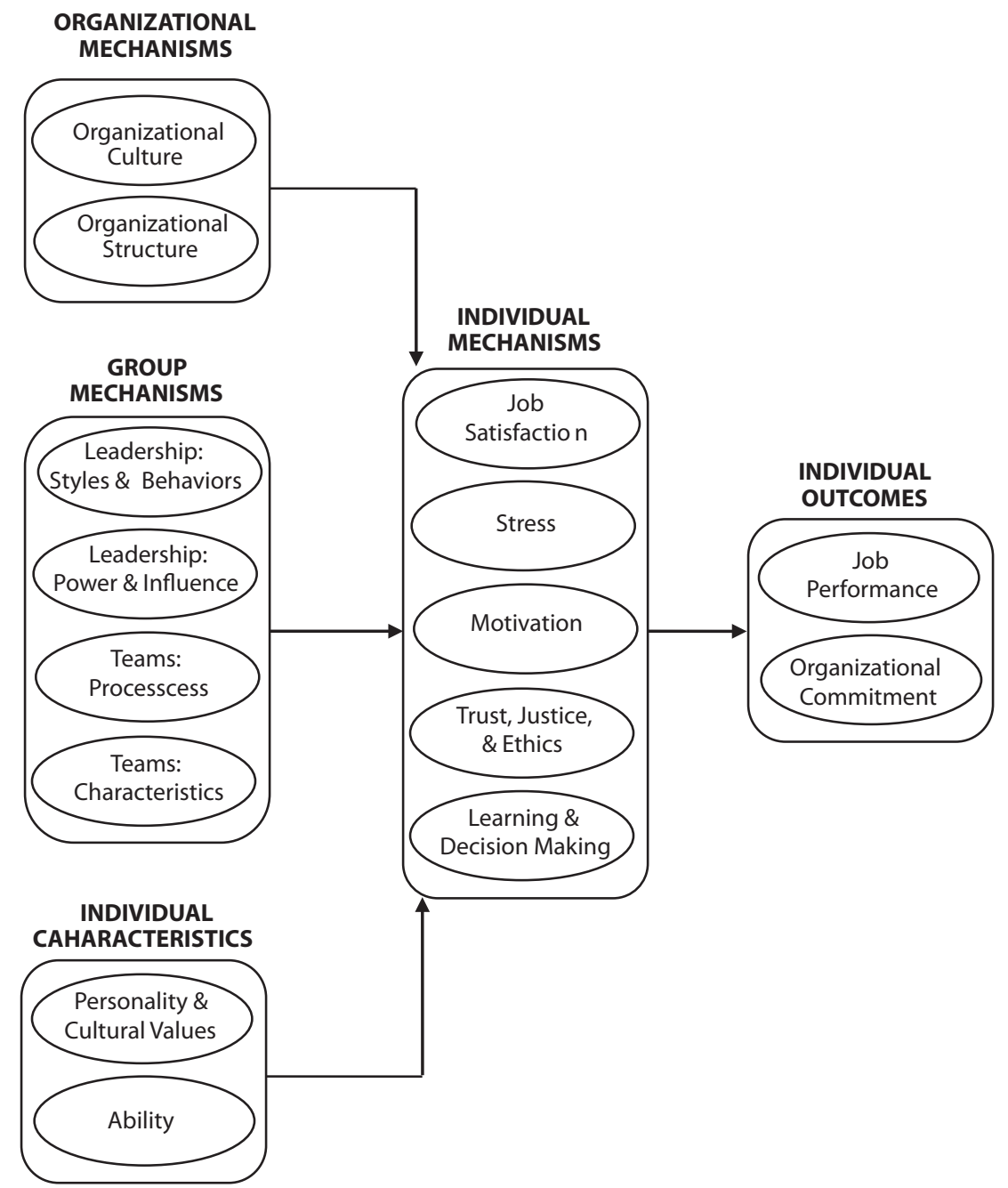

THE EFFECTS OF ORGANIZATIONAL CULTURE

Sri Yanti, Jarnawi Afgani Dahlan 
THE EFFECTS OF ORGANIZATIONAL CULTURE

Sri Yanti,

Jarnawi Afgani Dahlan

\section{Research hypotheses}

Based on theoretical studies, relevant research results, and the above framework of thinking, the following research hypotheses are proposed: (1) Organizational culture has a direct positive effect on job satisfaction of employees of the Technical Implementation Unit of Tangerang Regency Education Office; (2) Organizational culture has a direct positive effect on the commitment of employees of the Technical Implementation Unit of Tangerang Regency Education Office; (3) Leadership behavior has a direct positive effect on job satisfaction of employees of the Technical Implementation Unit of Tangerang Regency Education Office; (4) Leadership behavior has a direct positive effect on the organizational commitment of employees of the Technical Implementation Unit of Tangerang Regency Education Office; (5) Job satisfaction has a direct positive effect on the organizational commitment of employees of the Technical Implementation Unit of Tangerang Regency Education Office.

\section{Research methodology}

This research was conducted with the aim to obtain valid data and information in order to find whether there is: (1) a direct effect of organizational culture on employee job satisfaction, (2) a direct effect of organizational culture on employee organizational commitment, (3) a direct effect of leadership behavior on employee job satisfaction, (4) a direct effect of leadership behavior on employee organizational commitment, and (5) a direct effect of job satisfaction on employee organizational commitment.

The research employed cross-sectional survey method with target population including all non-functional employees of the Technical Implementation Unit of Kindergarten, Primary School, and Non-formal and Informal Education of Tangerang Regency Education Office. The reachable population for sampling frame consisted of 175 non-functional employees, while the research samples included 121 employees. Sampling was done with proportionate random sampling technique, according to the distribution of non-functional staff in each Technical Implementation Unit at the Education Office of Tangerang Regency.

The data were collected using questionnaires in the forms of Likert scale and rating scale. Data were analyzed with descriptive and inferential statistical analyses. Descriptive statistical analysis includes the mean, median, mode, standard deviation, variance, maximum and minimum score, and frequency distribution and histogram. Meanwhile, inferential statistical analysis used the Structural Equation Modeling (SEM) formula.

From the results of the SEM analysis to the cultural variables, it is known that the testing of model fit index showed that most indexes (P $\left(\chi^{2}\right)$, GFI, AGFI, NFI, NNFI, CFI, IFI, RFI, CFI and IFI) have meet the criteria. Only one index doesn't meet the criteria, ie RSMEA $=0.107>0.08$ (Appendix 1). As that most indexes 
have met the criteria, it can be concluded that the model of organizational culture variable is corresponding in the theoretical model and the empirical model. The leadership variables from fit model meets the criteria in most indexes (NFI, NNFI, CFI, IFI, and RFI). However, the $\mathrm{P}\left(\chi^{2}\right)=0.00<0.05$, GFI and AGFI <0.9. As the most indexes have met the criteria, it can be concluded that the model of leadership behavior variable is corresponding in the theoretical model and the empirical model. For job satisfaction, it is revealed that all indexes of fit model, (P $\left(\chi^{2}\right), \mathrm{RMSEA}, \mathrm{GFI}, \mathrm{AGFI}, \mathrm{NFI}, \mathrm{NNFI}, \mathrm{CFI}$, IFI and RFI) have met the criteria. As for work commitment variable, the calculation using fit model resulted $\mathrm{P}$ value $\left(\chi^{2}\right)$ equal to $1.00>0.05$ and $\mathrm{RMSEA}=0.00<0.08$. These results indicate that the organizational commitment variable model with the three indicators is fit or theoretical model is in accordance with the empirical model. Thus it can be concluded that the variable model of job satisfaction corresponding in theoretical models and empirical model. Eventually, from the measurement of latent variables of work culture, leadership, job satisfaction, and work commitment can be concluded that the empirical model is in accordance with theoretical model.

\section{Discussion}

Before discussing the results of the following research, the results of path analysis calculations using LISREL software is presented (see Appendix 2). From the calculation results is known that each indicator on each research variable has a significant loading factor value.

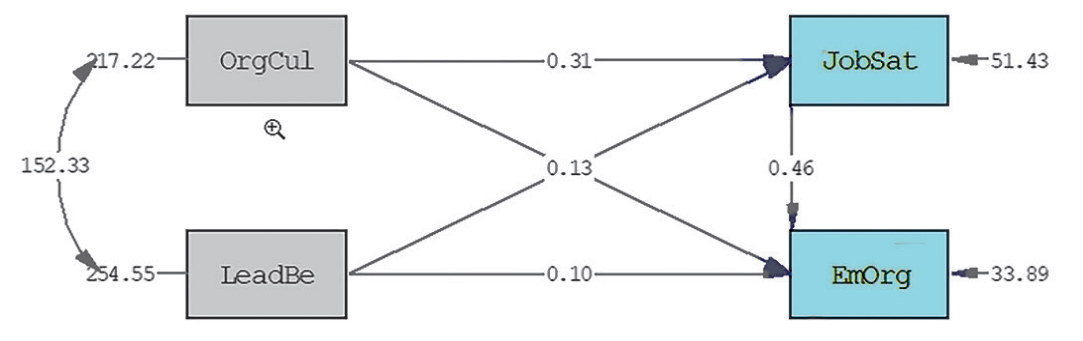

Chi-Square=-0.00, df=0, P-value=1.00000, RMSEA=0.000

From the results of LISREL calculation, it is known that the probability value of Chi Square and RMSEA as follows:

The table showed that the value of significance or p-value for Chi Square (1.000) is greater than 0.05 and RMSEA (0.000) is less than 0.08. These results

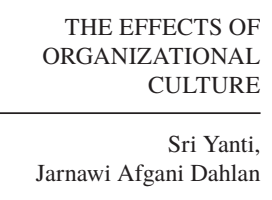

THE EFFECTS OF CULTURE

ni Dahlan (1) 
Table 1.

Index of model accuracy

\section{Figure 3.}

Substructural equation 1 and its significance

indicate that the model under test has represented or corresponds to the structure of the equation based on empirical data.

\begin{tabular}{lccc}
\hline Index & Result & Standard Value & Conclusion \\
\hline $\mathrm{P}\left(\chi^{2}\right)$ & 1.00 & $>0.05$ & Good fit \\
\hline RMSEA & 0.00 & $<0.08$ & Good fit \\
\hline
\end{tabular}

Furthermore, from figure 2 also obtained the structural equation. Given that in this study there are two endogenous variables (Job satisfaction (JobSat) and Employee Organizational ( $\mathrm{EmOrg})$ ), then obtained two structural equations. The first structural equation is Job Satisfaction as endogenous variable and Organizational culture $(\mathrm{OrgCul})$ and Leadership Behavior (LeadBe) as exogenous variable, which can be as follows:

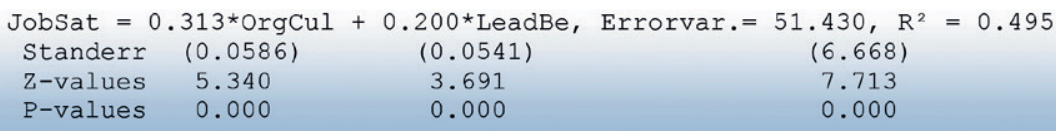

From the equation is known that for organizational culture variable, coefficient of structural equation is 0.31 and for leadership behavior is 0.20 with significance of both coefficient is 0.00 . The value of both structural coefficients is positive, this indicates that the influence of organizational culture and leadership behavior is positive. Moreover, the model that links the relationship between Organizational culture and Leadership Behavior with Job Satisfaction is very meaningful. The influence from organizational culture and leadership behavior to job satisfaction is considerably high, that is 0.49 or $49 \%$. Thus, it can be concluded that both individually and together the variables of organizational culture and leadership behaviors have a significant effect on Job Satisfaction.

The second structural equation is the endogenous variable Employee Organizational Commitment (EmOrg), and the exogenous variables of Job satisfaction (JobSat), Organizational culture $(\mathrm{OrgCul})$ and Leadership Behavior $(\mathrm{LeadBe})$, the following equations are obtained:

Figure 4.

Substructural equation 3 and its significance

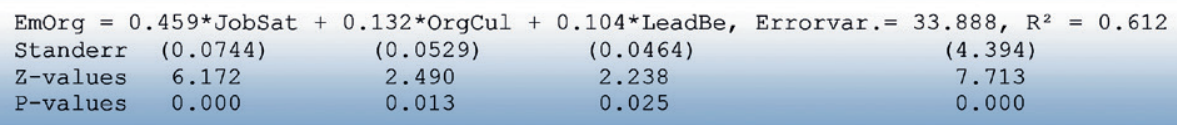


In the sub structural in figure 4 (equation 3), it is known that organizational commitment is influenced by organizational culture variable with structural coefficient 0.46 , leadership behavior with structural coefficient 0.13 and job satisfaction with structural coefficient 0.10. All structural coefficients are positive, indicating that the three variables have a positive effect. The overall path coefficients of the three exogenous variables to their endogenous variables (EmOrg) is very significant.

It means the joint influence of organizational culture, leadership behavior and job satisfaction on workers' organizational commitment is very significant, with the value influence of 0.61 or $61 \%$.

\section{Direct Effect of Organizational Culture on Job Satisfaction}

The result of the first hypothesis testing shows that organizational culture had a positive and significant impact on job satisfaction. This result confirms that the implementation of a good organizational culture will have implications for increased job satisfaction. This tendency can be understood because everyone wants satisfaction. Likewise, employees need job satisfaction. This satisfaction can be obtained from such aspects of work as wages, employment, promotion, supervision, colleagues, and working conditions. The work aspects perceived positively and therefore felt to be pleasant will bring job satisfaction. But there are times when these aspects are not in accordance with the expectations, needs, and interests of employees so that they fail to bring pleasure that can lead to job satisfaction. This is as proposed by Sutrisno (2017) and Sayles (Sutrisno, 2017) that an employee who does not get job satisfaction will never achieve psychological satisfaction and eventually will arise a negative attitude or behavior, that will lead to frustration, lost of the spirit and can not excel in work.

The work aspects can bring a sense of satisfaction among employees when supported by conducive internal condition of the organization, especially the organizational culture. In this sense, organizational culture is a collection of fundamental values, norms, and beliefs shared by members of the organization in order to achieve organizational goals. This means that employee job satisfaction will be achieved when the organizational culture that is built, grown, and developed within the organization accommodates and aligns with the expectations, needs, and interests of employees on all the desired aspects of the work.

Organizational culture has a number of important roles that can lead to job satisfaction. This is as suggested by Robbins (2006) that organizational culture, among others, serves to (1) set boundaries, (2) foster a sense of identity for its members; (3) foster a shared rather than individual commitment; (4) enhance social stability, and (5) be the mechanisms for the creation of meaning and control that guide and shape the attitudes and behaviors of members of the organization.
THE EFFECTS OF ORGANIZATIONAL CULTURE

Sri Yanti,

Jarnawi Afgani Dahlan 
THE EFFECTS OF ORGANIZATIONAL CULTURE

Sri Yanti,

Jarnawi Afgani Dahlan
Such functions as identity growth, commitment growth, and social stabilization can lead to job satisfaction.

Previous research also provides evidence that organizational culture has an effect on job satisfaction. This can be traced from the results of research conducted by Silverthorne (2004) in Taiwan. The results of his research prove that organizational culture has a positive influence on job satisfaction. Sosa and Sagas's research (2006) also shows that culture has a significant relationship with job satisfaction. The result of the present study further confirms the importance of organizational culture in increasing job satisfaction. This means there is a correspondence between theory and empirical findings.

\section{Direct Effect of Organizational Culture on Organizational Commitment}

The result of the second hypothesis testing shows that organizational culture had a positive and significant effect on organizational commitment. This result indicates that the implementation of a good organizational culture will have positive implications for the improvement of organizational commitment. This tendency can be understood because organizational culture is a collection of basic values, norms and beliefs that are built, developed, and shared by all members of the organization that are relied upon to achieve organizational goals. Organizational culture also characterizes the uniqueness of an organization and therefore reflects the organizational personality. Therefore, an organizational culture that harmonizes, suits, and accommodates the expectations, interests, and needs of as many members of the organization as possible tends to be viewed positively by members of the organization. Conversely, an organizational culture that is not aligned with the aspirations of members of the organization is seen as negative, and therefore will not be supported.

The creation of an organizational culture that is viewed as positive and conducive will trigger in the employees an interest in the organization and then enable the growth of a sense of self-identification of organizational values and objectives, the desire to engage and participate actively in the organization, and the motivation to survive in the interest of the organization. These are all manifestations of organizational commitment, so that organizational culture will have an influence on organizational commitment.

As explained earlier, organizational culture has a number of important functions, among which is fostering mutual rather than individual commitment (Robbins, 2006). From this function, it can be seen that organizational culture has a positive impact to foster organizational commitment. One of the studies of the relationship between organizational culture and organizational commitment include that by Ingelsoll et al. (2000). The results of the study show that organizational culture is a strong predictor in creating employee commitment to the organization. Studies by Chatman, Denison, Smith, Rupp, and Chin et 
al. also demonstrate that a good organizational culture will create commitment among members of the organization and help direct individual goals towards organizational goals (Cannesa and Riolo, 2003). Thus, the result of the current study further reinforces the findings that organizational culture has an effect on organizational commitment.

\section{Direct Effect of Leadership Behavior on Job Satisfaction}

The result of the third hypothesis testing indicates that leadership behavior had a positive and significant effect on job satisfaction. This finding suggests that the implementation of good leadership behavior will have positive implications for increased job satisfaction. This tendency can be understood, given that leadership has a central role in the organization. Leadership is a major pillar in the dynamics of organizational life. Thus, it is not surprising that a leader is a representation of the organization. The central position of the leader is what causes a leader's behavior to always be the center of attention, and therefore a leader's behavior in planning, organizing, solving problems, explaining organizational goals, informing, motivating, inspiring, delegating authority, supporting, developing and guiding subordinates, managing conflict, building teams, developing networks, and giving recognition and rewards is crucial to the organizational life.

Such conditions allow leadership behavior to either directly or indirectly involve all members of the organization. Leadership behavior that is in accordance with the expectations, needs, and interests of subordinates will be perceived positively and bring a sense of pleasure. Pleasure will then trigger satisfaction in work. A leader also plays a role in motivating, empowering, being a role model, and providing feedback for the subordinates. If such functions are done well, employees will have job satisfaction.

The results of previous studies also provide evidence that leadership behavior has an effect on job satisfaction. This is as reported in the research conducted by Menaker and Bahn (2008) which demonstrates that leaders who often show honesty have a strong relationship with job satisfaction. Rad and Yarmohammadian's research (2006) also shows leadership has a relationship with employee job satisfaction. The results of the two previous studies make it clear that leadership behavior is a factor that affects job satisfaction. Thus, this study further supports findings of previous research on the effect of leadership behavior on job satisfaction.

\section{Direct Effect of Leadership Behavior on Organizational Commitment}

The result of the fourth hypothesis testing shows that leadership behavior had a positive and significant effect on the organizational commitment of employees. This finding indicates that a leader's ability to demonstrate behavior in accordance with employees' expectations will have positive implications for the improvement
THE EFFECTS OF ORGANIZATIONAL CULTURE

Sri Yanti,

Jarnawi Afgani Dahlan 
THE EFFECTS OF ORGANIZATIONAL CULTURE

Sri Yanti,

Jarnawi Afgani Dahlan of organizational commitment. This condition can occur because an organization cannot possibly grow and develop without the presence of a leader. This means that a leader is the spirit of the organization. A leader is the icon of the organization, so whatever the leader does will always be the attention of the subordinates. A leader's words, attitudes, and behaviors are always the center of attention. Therefore, when the leader's behavior is in accordance with the actual condition of the subordinates, in the sense of being aligned with the needs, expectations, interests, and tastes of the subordinates, it will be perceived and received positively by the subordinates. This in turn will encourage the subordinates to support the leadership and make them willing to do best in the organization led by the leader. This willingness is a reflection of organizational commitment.

Previous studies also emphasize that leadership behavior is a factor that affects organizational commitment. This can be seen, among others, from the research conducted by Walumbwa et al. (2005). The results prove that a leader who performs transformative leadership has a strong effect on the organizational commitment of the employees. The results of Walumbwa et al.'s (2005) study assert that leadership behavior has an effect on organizational commitment. Thus, the result of this study further strengthens the results of previous research on the effect of leadership behavior on organizational commitment.

\section{Direct Effect of Job Satisfaction on Organizational Commitment}

The result of the fifth hypothesis testing shows that job satisfaction had a positive and significant effect on organizational commitment. This finding indicates that good work satisfaction will have positive implications for increased organizational commitment. This finding is understandable because a commitment is established when the aspects of work, such as wages, employment, promotion, supervision, partners, and working conditions are perceived and received positively by members of the organization (employees) to satisfy themselves. When all aspects of work are perceived positively and therefore are regarded as being pleasurable by employees, the employees will be encouraged to commit to the organization. Thus, it can be expected that job satisfaction has a direct effect on organizational commitment.

The results of previous studies also reinforce the finding in this study, such as those by Lincoln and Kalleberg, Mowday, Porter, and Steers, Mueller, Boyer, Price and Iverson, and Williams and Hazer (as quoted in Slattery and Selvarajan, 2005). Thus, the result of this study further reinforces that job satisfaction is a predictor of organizational commitment

\section{Research limitations}

The limitations in this study include: (1) the population of this study was limited to the Technical Implementation Unit of Kindergarten, Primary School, and Non- 
Formal and Informal Education of the Education Office in Tangerang Regency, so that the results cannot be generalized to include all technical implementation units at the Education Office of Tangerang Regency and especially in other areas; and (2) this study only involved three variables, namely organizational culture, leadership behavior, and job satisfaction as the factors affecting organizational commitment. However, there are other factors that may potentially affect organizational commitment, namely: work motivation, compensation, self-efficacy, career development, emotional intelligence, organizational communication, and locus of control. Hence, other factors that may potentially affect organizational commitment are not uncovered in this study.

\section{Conclusions and suggestions}

Based on the analysis of research results and discussion in the previous sections, the following conclusions can be drawn:

1) Organizational culture had a direct positive effect on employee job satisfaction. This means that a strong organizational culture can increase employee job satisfaction.

2) Organizational culture had a direct positive effect on the organizational commitment of employees. This means a strong organizational culture can increase employee organizational commitment.

3) Leadership behavior had a direct positive effect on employee job satisfaction. This means positive leadership behavior can improve employee job satisfaction.

4) Leadership behavior had a direct positive effect on employee organizational commitment. This means positive leadership behavior can increase employee organizational commitment.

5) Job satisfaction had a direct positive effect on employee organizational commitment. This means that high job satisfaction can increase employee organizational commitment.

6) The variations in employee organizational commitment are directly influenced by organizational culture, leadership behavior, and job satisfaction.

Referring to the conclusions, the following recommendations can be made:

1) All employees should be given an understanding about the importance of organizational culture in order to improve job satisfaction and organizational commitment, so that employees can grow their awareness to implement, maintain, and preserve the values of organizational culture, with their leader as a role model. In addition, leaders need to be role models for their subordinates in implementing the values of organizational culture.

2) Leaders need to self-evaluate their leadership by, among others, requesting input from subordinates who always interact with them.
THE EFFECTS OF ORGANIZATIONAL CULTURE

Sri Yanti,

Jarnawi Afgani Dahlan 
THE EFFECTS OF ORGANIZATIONAL CULTURE

Sri Yanti,

Jarnawi Afgani Dahlan
Leaders should continue improving their leadership competence in order to find more effective leadership.

3) Management team and leaders need to be aware of the importance of job satisfaction in order to increase the organizational commitment of employees that will contribute positively to their performance, taking into account factors affecting job satisfaction.

4) It is necessary to conduct further research on organizational commitment to confirm other factors that affect organizational commitment, such as work motivation, compensation, self-efficacy, career development, emotional intelligence, organizational communication and locus of control.

\section{References}

Azwar, S. (2000), Sikap Manusia dan Pengukurannya (Human Attitudes and Their Measurements). Pustaka Pelajar Yogyakarta, Yogyakarta.

Azwar, S. (2003), Reliabilitas dan Validitas (Reliability and Validity). Pustaka Pelajar, Yogyakarta.

Canessa, E., Rick, L.R. (2003), "The Effect of Organizational Communication Media on Organizational Culture and Performance: An Agent-Based Simulation Model", Computational \& Mathematical Organizational Theory, Vol. 9 No. 2, pp. 147-176.

Colquitt, J.A., LePine, J.A., Wesson, M.J. (2009), Organizational Behavior: Improving Performance and Commitment in the Workplace. McGraw-Hill, New York.

Greenberg, J., Baron, R.A. (2008), Behavior in Organizations: Understanding and Managing the Human Side of War, Prentice Hall International, New Jersey.

Ingersoll, D.K., Kirsch, J.C., Merk, S.E., Lightfoot, J. (2000), "Relationship of Organizational Culture and Readiness for Change to Employee Commitment to Organization", Journal of Nursing Administration, Vol. 30 No. 1, pp. 11-20. DOI: 10.1023/B:CMOT.0000022753.91962.99

Menaker, R., Bahn, R.S. (2008), "How perceived physician leadership behavior affects physician satisfaction", Mayo Clinic Proceedings, Vol. 83 No. 9, p. 983.

Nelson, D.L., Quick, J.C. (2006), Organizational Behavior: Foundations, Realities \& Challenges, South-Western, Ohio.

Newstrom, J.W. (2007), Organization Behavior: Human Behavior at Work, McGraw Hill, Boston.

Noe, R.A., Hollenbeck, J.R., Gerhart, B.A., Wright, P.M. (2006), Human Resource Management. McGraw-Hill Irwin, Boston.

Rad, A.M.M., Yarmohammadian, M.H. (2006), "A study of relationship between managers' leadership style and employees' job satisfaction”, Leadership in Health Services, Vol. 19 No. 2.

Robbins, S.P., Judge, T. (2009), Organizational Behavior, Pearson Prentice Hall, New Jersey.

Robbins, S.P. (2006), Perilaku Organisasi (Organizational Behaviors), Jakarta.

Schein, E.H. (2004), Organizational Culture and Leadership, Jossey-Bass, San Fransisco. Silverthorne, C. (2004), "The impact of organizational culture and person-organization 
fit on organizational commitment and job satisfaction in Taiwan", Leadership \& Organization Development Journal, Vol. 25 No. 7/8.

Slattery, J.P., Selvarajan, T.T.R. (2005), “Antecendents to Temporary Employee's Turnover Intention", paper presented for the Organizational Behavior and Organizational Theory, 31 March 2005, Midwest Academy of Management Annual Meeting.

Sosa, J., Sagas, M. (2006), Assessment of organizational culture and job satisfaction in national collegiate athletic association academic administrators, A\&M UniversityCollege Station, Texas.

Sutrisno, E. (2017), Manajemen sumber daya manusia, Prenadamedia Group, Jakarta.

Walumbwa, F.O., Orwa, B., Wang, P., Lawle, J.J. (2005), “Transformational leadership, organizational commitment, and job satisfaction: a comparative study of Kenyan and U.S. Financial Firms", Human Resource Development Quarterly, Vol. 16, No. 2.

Wiwoho, R.H. (2004), Reframing: Kunci Hidup Bahagia 24 Jam Sehari (Reframing: The Key to a Happy Life 24 Hours a Day), Gramedia, Jakarta.

Zachary, W.B., Kuzuhara, L.W. (2005), Organizational Behavior: Integrated Models and Applications, Thomson, Ohio.

Zhu, W., Chew, I.K.H., Spangler, W.D. (2005), "CEO Transformational Leadership and Organizational Outcomes: the Mediating Role of Human Capital Enhancing Human Resource Management", The Leadership Quarterly, Vol. 16, p. 39-52. DOI: 10.1016/j. leaqua.2004.06.001
THE EFFECTS OF ORGANIZATIONAL CULTURE

Sri Yanti, Jarnawi Afgani Dahlan 
THE EFFECTS OF ORGANIZATIONAL CULTURE

Sri Yanti,

Jarnawi Afgani Dahlan

SEM of employee organizational commitment

\section{Appendix 1.}

Structure equation model of exogenous variables
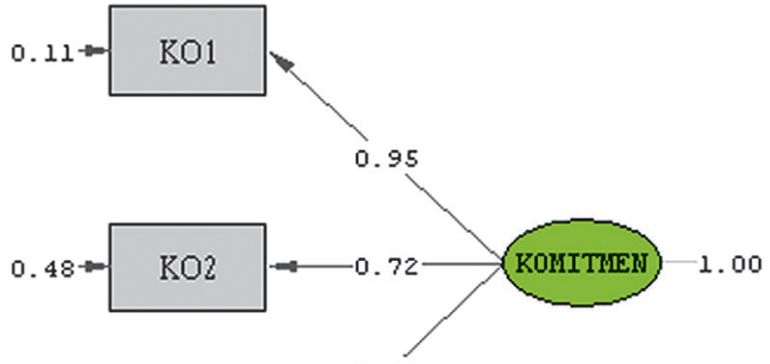

$0.59+\mathrm{KO} 3$

0.64

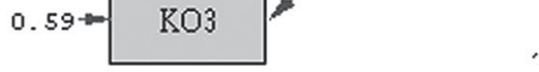

Chi-Square=0.00, df=0, p-value=1.00000, RISEA=0.000

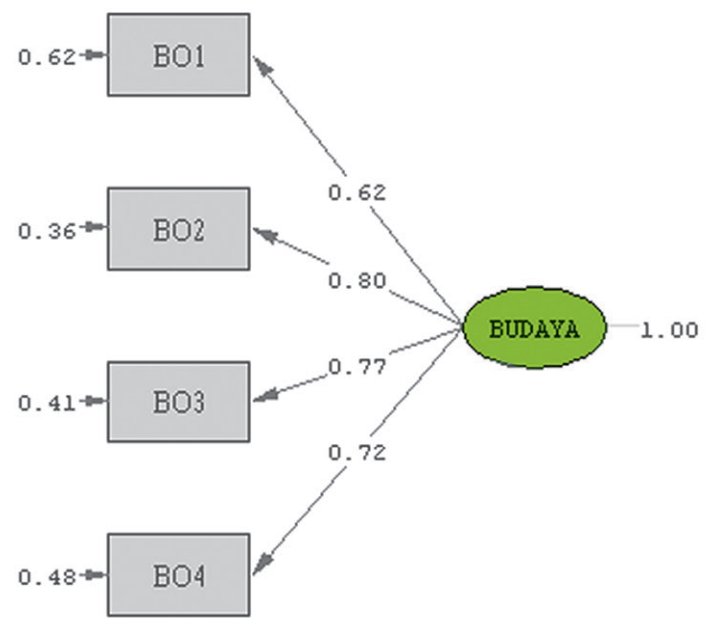

SEM of organizational culture

Chi-square=4.73, $d f=2, \quad$-value=0.09389, RMSEs=0.107 


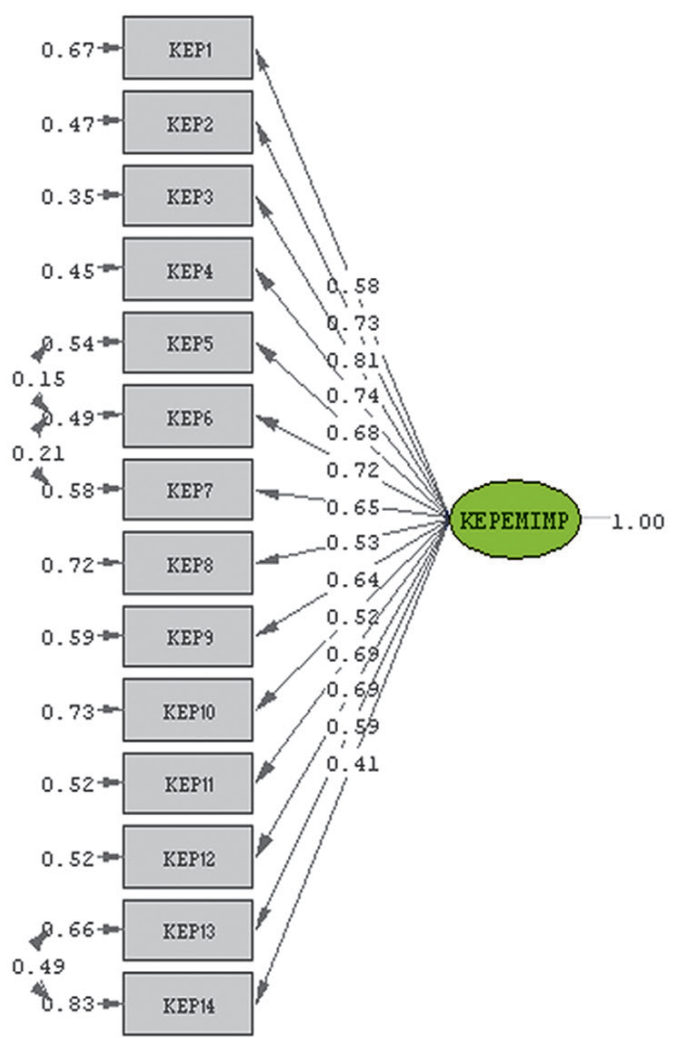

Chi-square $=128.38, d f=74, P-v a l u e=0.00009$, RMSEd $=0.078$
THE EFFECTS OF ORGANIZATIONAL CULTURE

Sri Yanti, Jarnawi Afgani Dahlan
SEM of leadership behavior

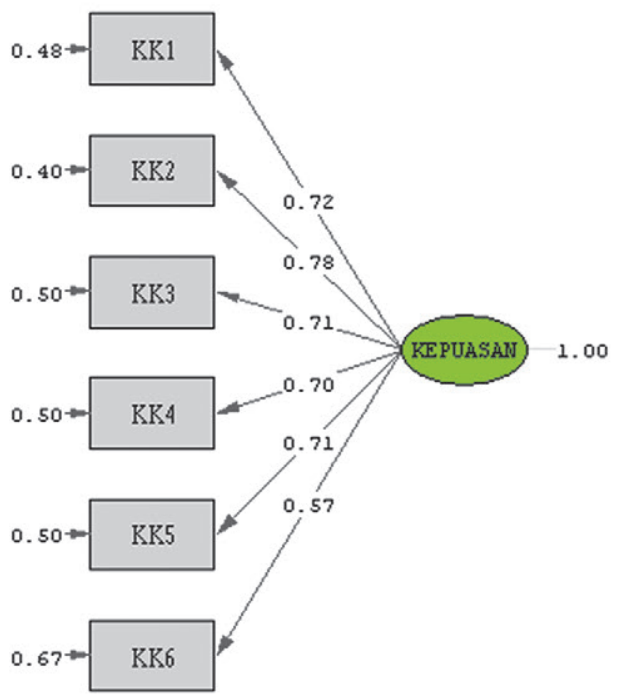

Chi-Square $=11.80, d f=9, p-v a l u e=0.22498$, RMSER $=0.051$

SEM of job satisfaction 
THE EFFECTS OF ORGANIZATIONAL CULTURE

\section{Sri Yanti,}

Jarnawi Afgani Dahlan

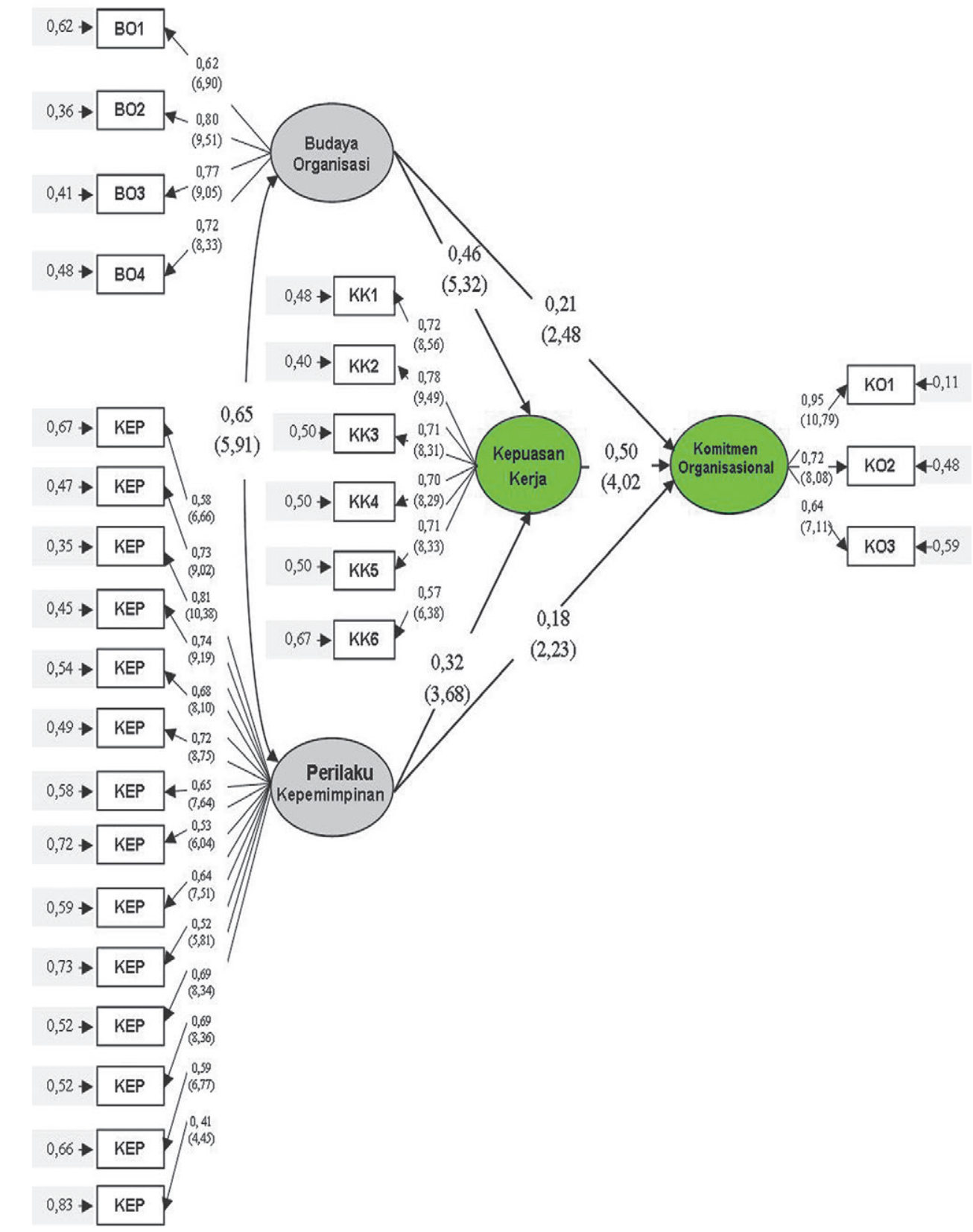

Appendix 2.

Path analysis of exogenous and endogenous variables 